\title{
Jak drapieżny ptak chcę okrążyć miasto. Egon Schiele - melancholik skandalista
}

\section{I want to fly around the city as a rapacious bird. Egon Schiele - melancholic, scandalmonger}

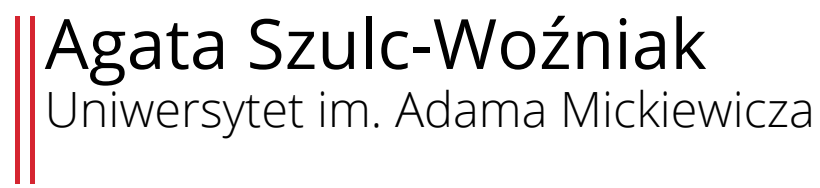

\begin{abstract}
Egon Schiele is one of the most distinctive painters of the early twentieth century. Known primarily as the author of scandalous acts. But also symbolic compositions, antropomorphic landscapes and still-life work for to his credit.

The article presents the silhouette of the artist - egocentric, rebelious and eccentric. The artist who talks about his experience in a shamelessly open and honest way. The artist seeking knowledge about man in all of its abundance of uniqueness and weakness.

The text is an attempt to answer the question about the phenomenon of the Viennese painter who courageously followed melancholic clues in one of the groundbreaking moments in the history - the decaying era.
\end{abstract}

Key words: Egon Schiele, Gustav Klimt, Vienna Secession, melancholia, painting, expressionism, acts

Streszczenie: Egon Schiele to jeden $\mathrm{z}$ najbardziej charakterystycznych malarzy początku XX wieku. Znany przede wszystkim jako twórca skandalizujących aktów, ma w swoim dorobku również kompozycje symboliczne oraz pejzaże przedstawiające antropomorfizowane krajobrazy i martwe miasta.

Artykuł przedstawia sylwetkę malarza - egocentryka, buntownika, ekscentryka - artysty mówiącego o swoim doświadczeniu w sposób bezwstydnie otwarty i szczery, szukającego wiedzy o człowieku w całym bogactwie jego słabości i niezwykłości.

Tekst stanowi próbę odpowiedzi na pytanie o fenomen wiedeńskiego malarza, który z odwagą podążył za melancholijnymi tropami w jednym z przełomowych momentów historycznych - upadającej epoki.

Słowa kluczowe: Egon Schiele, Gustav Klimt, Secesja Wiedeńska, melancholia, malarstwo, ekspresjonizm, akty

Na Autoportrecie z 1911 roku dwudziestojednoletni wówczas Egon Schiele przedstawił się raczej kpiąco. Jeśli ironia malarza kierowała się ku podmiotowi twórczego namysłu, autor obrazu musiał już wtedy sporo 
o sobie wiedzieć. Na tyle, by z namysłem i świadomie kształtować swój wizerunek - i na tyle, by sprostać wrażeniu, jakie wywiera na odbiorcy.

Młody mężczyzna, którego chuda twarz o ostrych rysach i wybujała fryzura niemal nie mieszczą się na płótnie, wygląda niepokojąco. Przywodzi na myśl osobę ogarniętą niebezpieczną obsesją - postać zamkniętą w świecie niepodzielnie własnym i groźnym. W jego mimice, w postawie jest coś, co powoduje poczucie obcowania z wyniosłą siłą i charyzmą. Nie wiadomo, jak odpowiedzieć na śmiałe, zaczepne spojrzenie dużych oczu ukrytych pod półprzymkniętymi powiekami.

Pierwszy plan Autoportretu zajmuje wyrazisty, tajemniczy w wymowie gest dłoni z nienaturalnie długimi, szczupłymi palcami. Podobne znaki można odnaleźć na innych portretach i wielu autoportretach, a także na starannie wystudiowanych fotografiach Schielego, które zamawiał u najlepszych wiedeńskich fotografów. Charakterystyczny gest, nieco przypominający victorię, ale doprowadzony do ekspresyjnej ostateczności, do karykatury, granic ostentacji, wydaje się możliwy do zrozumienia tylko przez najbliższych - albo przez wtajemniczonych w wiedzę niedostępną przeciętnym odbiorcom. Monstrualne ręce młodzieńca z portretu wiodą ku popularnej na początku XX wieku chiromancji - czytaniu z dłoni. Można tylko snuć domysły, czy Schiele zaszyfrował w obrazie jakieś przekonania na swój temat - i dla kogo to wiadomość.

Adresat nadanego dłonią sygnału znajduje się naprzeciwko bohatera płótna, młodzieniec nieufnie mu się przygląda. Komu? Widzowi? A może samemu sobie, malującemu się z dumną śmiałością - twarzą w twarz?

Spojrzenie na siebie jak na obraz wymaga dystansu. Odegranie roli do płótna jak do lustra jest wyrazem opanowania i koncentracji. Narcyzm Schielego stanowi misternie przemyślaną konstrukcję, nie ma w nim miejsca na spontaniczny zachwyt, na poddanie się uwodzącej sile „ja”. Wydaje się, że Schiele chce pozostać nierozpoznany - i dla samego siebie, i dla odbiorcy - i nie zadowala się przy tym obojętnością towarzyszącą niekiedy kontaktom z tym, co niemożliwe do pojęcia. Nieodczytywalność ma być bolesna i wyraźna, ma zbliżać do obszarów szaleństwa, choroby, prowadzić $\mathrm{w}$ rejony ciemnej tajemnicy.

Czy można przypisać Schielemu takie intencje? Czy malarz nie dowierzał w możliwość pełnego pojęcia - i w możliwość porozumienia z odbiorcą? Jeśli tak - jego intuicja jest zaskakująco trafna. Zaledwie rok po ukończeniu Autoportretu artysta, który mieszkał wówczas z Wally, na spokojnych przedmieściach Wiednia, w Neulengbach, trafił do więzienia oskarżony o pornografię i niemoralność. Był oburzony - szczególnie tym, jak prostacko, jak wulgarnie daleka od jego intencji może być interpretacja obrazów.

To jest skandal! Prawie nie do uwierzenia brutalność! Podłość! Wielka, wielka głupota! Jest hańbą dla kultury, hańbą dla Austrii, że artyście w jego kraju może się coś takiego wydarzyć (...). Żadne erotyczne dzieło nie jest świństwem, jeśli 
jest tylko wartościowe artystycznie. Świństwem staje się dopiero dzięki widzowi (Urbanowicz 1997, 143).

Oskarżenia o uwiedzenie młodej dziewczyny, do których pretekst dały kontakty malarza z ubogimi szwaczkami i nastoletnimi sąsiadkami, pozującymi mu za niewielkie pieniądze, okazały się bezpodstawne (Kuryluk 1999, 38). Sędzia uznał jednak niektóre z rysunków Schielego za „pornografię dostępną nieletnim" i skazał go na trzy dni więzienia (Sabarsky 1996, 15).

Chociaż śmiały artysta był zbulwersowany, niezrozumienie i odrzucenie trudno uznać za nieoczekiwaną cenę bezkompromisowości, za niespodziewaną odpowiedź na obrazy wymyślnej rozpusty i wyuzdania. Aż do 1913 roku, kiedy w wieku zaledwie dwudziestu trzech lat został przyjęty do Stowarzyszenia Artystów Austriackich i jego kariera rozpędziła się, znajdując kulminację $\mathrm{w}$ sukcesie wystawy $\mathrm{w}$ pawilonie Secesji w 1918 roku, popularność Schielego ograniczała się przecież do „kręgu wiedeńskich kolekcjonerów pornografii" (Szarota 2013, 325). Chyba nie mogło to dziwić młodego twórcy, który - dzięki znajomości z ginekologiem Erwinem von Graffem - w 1910 roku zyskał pozwolenie na szkicowanie chorych i ciężarnych w wiedeńskiej klinice kobiecej (Werkner 1996, 42). Z tego okresu pochodzą między innymi Akt siedzacej kobiety i Akt siedzacej ciężarnej - porażające anatomiczną dosłownością. Fascynacja ciałem u Schielego wykracza jednak poza to, co kojarzy się z erotyką.

W swych autoportretach, w ekstatycznych aktach artysta szuka ukrytych, demonicznych, nieszczęśliwych stron ludzkiego życia; nie robi różnicy między nimi, a przedstawieniami „patologicznymi”. W tych obrazach zaciera się różnica między tym, co zdrowe, a tym, co chore, normalne i nienormalne, widać zwątpienie w gładką pozornie fasadę człowieka, ukrywającą jego rany i wrażliwość, ale także ciemną stronę jego człowieczeństwa (Werkner 1996, 42).

Porównując akty Schielego i Gustava Klimta, Piotr Krakowski zwraca uwagę na różny u obu artystów stosunek do voyeuryzmu. Erotyki autora Pocałunku przedstawiają sytuacje intymne - bohaterowie rysunków pozostają w naturalny sposób skupieni na sobie, nieświadomi bycia podglądanymi. Kobiece akty Schielego są natomiast silnie upozowane - modelki przyjmują sztuczne, ekshibicjonistyczne pozy, kojarzące się w najlepszym razie z bezwstydem, a często - z przemocą i dewiacją (Krakowski 1996, 35). Portretowane dziewczęta, jakby świadome tego, że są obserwowane, patrzą wprost na widza prowokacyjnie i wyzywająco albo, z twarzami jak wykute w drewnie, wpatrują się w nieodgadnioną dal (Fischer 1998, 47).

Słusznie zauważa Wolfgang Georg Fisher, że erotyki Schielego są naznaczone spojrzeniem lalkarza, który reżyseruje „ekspresjonistyczną kamasutrę". Bohaterkami przedstawień są modelki, traktowane jak martwe figury, pozbawione osobowości. Malarz zaopatrza je w kostiumy i rekwizyty - pończochy, bieliznę, buty i wstążki. Na obrazach Schielego przedmioty grają role seksualnych fetyszy (Werkner 1996, 44). 
Wymagający lalkarz rządzi spektaklem z pewnego oddalenia - szczególna perspektywa pozwala zachować bezpieczny dystans od pełnej dramatyzmu inscenizacji. Wiadomo, że w pracowni Schielego znajdowała się drabina, z której malarz chętnie korzystał. Wskazuje na to taki rysunek, jak choćby Akt leżacej kobiety w czarnych pończochach, którego bohaterka, obnażona i zamroczona, wydaje się kierować półprzytomny wzrok w górę.

Spojrzenie z wyżyn to spojrzenie władcy - tego, kto panuje i kto ustala reguły. Schiele doskonale zdawał sobie z tego sprawę. Mówiąc o swoich strategiach twórczych i o przedmiotach inspiracji, wydawał się zachłanny, lapczywy.

Jak drapieżny ptak chcę okrążyć miasto. Z tej perspektywy dostrzegam (...) zarówno panoramę miasta, jak akty. Obraz staje się ofiarą mojej woli. Muszę go mieć tylko dla siebie (Fischer 1998, 47).

W omówieniach twórczości Schielego wiele miejsca poświęca się wpływom wielkich malarzy, których obecność naznacza płótna autora. Zwraca się uwagę na związki z van Goghiem, Toulouse-Lautrekiem, Hodlerem, Munchem (Lionel, Armin 1996, 125). Nazwisko autora Śmierci i dziewczyny wymienia się też obok Cézanne’a czy Kandinsky’ego (Zeńczak 1997, 10). Zakrawa to na paradoks, biorąc pod uwagę, jak wiele Schiele poświęcił dla niezależności i jak unikał okazji do czerpania inspiracji z innych źródeł niż własne głębie.

Wiedeński malarz wyrósł z tradycji Secesji, grupy artystów działających w Wiedniu na przełomie XIX i XX wieku pod przewodnictwem Klimta, propagujących sztukę nowoczesną i szukających dla niej przestrzeni wolności. Secesjoniści nie tylko formułowali śmiałe założenia programowe, które bulwersowały mieszczańskie gusta, ale również organizowali wystawy prezentujące osiągnięcia ówczesnego malarstwa europejskiego. Dziedzictwo i artystyczne postulaty tego pokolenia, dla mniej uzdolnionych artystów nazbyt obciążające, dla Schielego stanowiły punkt wyjścia do własnych poszukiwań - i okazję do podejmowania artystycznego dialogu z innymi twórcami (Kuryluk 1974, 269).

Bystry rysownik, który oczarował Klimta, jeszcze zanim zaczął naukę u wielkich mistrzów, i który, jak podkreślają krytycy, wyzwolił się spod jego wpływu już jako dwudziestolatek, porzucił studia w Akademii Sztuk Pięknych w Wiedniu zaledwie trzy lata po ich rozpoczęciu, uznając środowisko akademickie za nazbyt zachowawcze. Wydaje się, że nie tylko on był rozczarowany pracą w formule uczeń-mistrz. Nauczyciel młodego adepta sztuki, Christian Griepenkerl, zniechęcony pogłębiającymi się konfliktami ze studentem, miał kiedyś zawołać: „Diabeł przywiódł Schielego do mojej klasy" (Sabarsky 1996, 12).

Po opuszczeniu akademii młody malarz założył z przyjaciółmi NeukunstGruppe. W magazynie „Die Aktion” opublikowali manifest, w którym głosili pochwałe "artysty nowego" - tego, kto w pełni realizuje własne wizje 
artystyczne, kto tworząc, wyraża siebie i nie bierze pod uwagę wymogów tradycji czy ugruntowanych konwencji przedstawieniowych (Krakowski 1996, 28). Strategia osadzania Schielego w znanych kontekstach sztuki, nurtach i stylistykach wskazuje, jak bardzo wiedeński malarz wymyka się możliwości klasyfikacji. Im więcej twórczych podobieństw, paralel odnajduje się dla Schielego, tym wyraźniej można wyczuć, że jego twórczość pozostaje osobna, naznaczona wielkimi, osobistymi dramatami, intymnością w odczuwaniu siebie i świata.

Rzadko kiedy dziedziny życia i twórczości, biegnące równolegle, więc prowokujące monografistów do szukania analogii, uzupełniają się tak jak u Schielego. Całe życie autora Autoportretu wydaje się dopełnieniem i dopowiedzeniem jego skandalizującej sztuki: trudne dzieciństwo naznaczone chorobą i śmiercią najstarszej siostry i ojca, bliska relacja z Gerti Schiele, pierwszą modelką, związek z podobną do niej, nastoletnią Wally Neuzil i kolejne przeprowadzki na prowincję - ucieczki przed krytyką opinii społecznej. Bulwersującym zainteresowaniom w planie twórczości odpowiadają afery i kompromitacje w planie życia: oskarżenia o pornografię zakończone pobytem w więzieniu, nagłe zerwanie relacji z wieloletnią przyjaciółką dla małżeństwa z dobrze sytuowaną Edith Harms, zawartego wbrew woli rodziców dziewczyny, i wreszcie śmierć - przedwczesna, niespodziewana, jako jedyne możliwe zakończenie tego życia, pełnego sprzeczności, paradoksów, pełnego bólu i niezrozumienia.

Bliscy Schielego wspominają jego narcyzm, egocentryzm, tendencję do dominacji. Siostra malarza, Gerti, w czasach, kiedy była jego modelką, skarżyła się na autorytaryzm brata: „Rano przychodził do mojego łóżka z zegarkiem w ręku, aby mnie budzić. Miałam być jego modelką na każde skinienie" (Szarota 2013, 332). W podobny sposób Schiele odnosił się do matki. Śladów egocentryzmu dostarcza jednak przede wszystkim jego twórczość, koncentrująca się na „ja” - „ja” malowanym i „ja” malującym.

Jak zatem rozumieć słowa jednego z przyjaciół Schielego, wielokrotnie przez niego portretowanego, Ericha Lederera, „Spośród wielu ludzi, których znałem, Egon Schiele był jednym z najnormalniejszych" (Sabarsky 1996, 10)? Jak pogodzić mroczne obszary życia z przekonaniem, które coraz częściej pojawia się w krytycznych opracowaniach twórczości malarza, o pielęgnowanym przez niego upodobaniu do mieszczańskiego stylu życia, mieszczańskich ideałów? Serge Sabarsky pisze:

Wielu biografów Schielego nie zauważa najważniejszych cech jego charakteru: naturalnej, zawadiackiej otwartości i bezpośredniości, które krytykom jemu współczesnym i dzisiejszym każą postrzegać go jako dziwaka. Schiele pokazywał wszystko, co go poruszało, tak bezpośrednio i bez zastrzeżeń, jak sam to odczuwał, a jego niezdolność do obłudnego purytanizmu wpędzała go w kłopoty (Sabarsky 1996, 11).

Najednym z rysunków, które stworzył w celi, Schiele napisał: „Uwielbiam sprzeczności”. Fascynacji tej dał wyraz w twórczości - w której wybujałe 
życie, w całym swym gorszącym rozmachu, gorączkowej obsesji trwania, spotykało się z grozą śmierci. Prowokacyjne pozy modelek, naznaczone były konwulsjami, dotknięte spazmami bólu lub rozkoszy. Niemożliwe do oddzielenia złączenie erotyki i śmierci, piękna i brzydoty, nadały twórczości Schielego rys nierozstrzygalności, pozostawiły ją na zawsze otwartą dla interpretacji.

Oksymoroniczny żywioł twórczości wiedeńskiego malarza bywa tłumaczony historycznie - „janusowym obliczem” schyłku monarchii, atmosferą, w której beztroska naznaczona jest bolesnym rewersem - przeczuciem upadku, końca (Zeńczak 1997, 11). Motywacja taka nie wyczerpuje jednak fenomenu twórczości Schielego - mającej źródło w bezpośrednim, szczerym odczuciu rzeczywistości. Autor godził paradoksy dlatego, że doświadczał świata przez pryzmat bolesnej, twórczej wrażliwości. Nie uciekał przed podejmowaniem nieustannego wysiłku czucia i nazywania. „Wydaje się (...), że dzieła Schielego mówią o życiu bardzo prawdziwie, choć nie o całej naszej egzystencji, ale o jej ciemnych stronach" - zauważa krytyk (Sarzyński 1997, s. 54).

Jeden z obrazów, Eremitów, przedstawienie dwóch pochylonych ku sobie postaci (Schielego - syna i Klimta - ojca), malarz opisał ze szczególną wnikliwością. W liście do kolekcjonera Carla Reininghausa podkreślił, że bohaterami płótna są ludzie, którzy silnie odczuwają, którzy dążąc do stworzenia samych siebie, załamują się w bezsilności.

Co ciekawe, Eremitów Schiele podpisał swoimi imieniem i nazwiskiem aż trzykrotnie. Fischer komentuje ten zabieg, przeczuwając intencję autora i nazywając ją: „tu jestem i nie potrafię inaczej” (Fischer 1998, 122-123). Malarz musiał wiedzieć, że jego wielkość jest „siłą fatalną” - jak melancholijne „spotęgowane doświadczenie własnego >ja<" (Klibansky, Panofsky, Saxl 2009, 264).

To, co stanowi o powierzchniowym obrazie twórczości wiedeńskiego artysty, nie dociera więc do głębi - głębi, której patronuje czarne słońce. Spojrzenie Schielego jest dotknięte przeczuciem utraty. Może dlatego jego akty wyrażają brak wiary w sens - sens piękna, miłości, zjednoczenia. Może dlatego oczy jego modelek pozostają puste, a ich postaci - martwe jak marionetki. W charakterystyczny sposób Schiele pisze o swoim dzieciństwie:

Często płakałem, gdy była jesień. Wiosną śniłem o wielkiej orkiestrze życia (...). Do tej pory życie mijało mi w radości, na przemian pogodnej i melancholijnej, potem nadeszły czasy próżniactwa i bezduszne szkoły (...). Dostałem się do miast ciągnących się bez końca i jakby martwych i pogrążyłem się w smutku (Kuryluk 1974, 265).

Interesujące, że właśnie na płótnach przedstawiających pejzaże wiedeński malarz tak czytelnie i tak wprost mówi o bólu i utracie - o smutku, który - obecny w ostentacyjnej brzydocie, wynaturzeniu lub ekspresyjnym krzyku - naznacza przecież i inne tematycznie obszary przedstawień. 
Obrazy natury poddane są psychizacji i znaczą przez swoje antropomorficzne odniesienia (Krakowski 1996, 29). Schiele często maluje jesienne i zimowe drzewa - pozbawione liści, kruche, targane przez wiatr. Słabe jabłonie i wiotkie kasztany stanowią metaforę cierpienia, sugerują przedstawienia udręczonych ciał (Kuryluk 1974, 275). Ludzkie analogie można odnaleźć również w wizerunkach wsi i miasteczek, np. często powracającego na płótnach Krumlova, rodzinnej miejscowości matki malarza. Wpisane w przedstawienia obrazy i metafory stanów psychicznych świadczą o tragicznej niemożności ucieczki poza dojmujące doświadczenia bólu, doświadczenia dramatu egzystencji, skażonej śmiercią. „Dachy, ściany, okna domów mają własną fizjognomię, swą mimikę, swoje twarze, wykrzywione w różne grymasy" (Kuryluk 1974, 31).

Pejzaże Schielego stały się ważną inspiracją poetycką. Do przedstawień pustych przestrzeni miejskich odwołuje się Jakub Kornhauser, autor cyklu Martwe miasto, Schiele. W poetyckich spostrzeżeniach, przywodzących na myśl ekfrazy, kryje się tajemnica artystycznego współodczuwania. Tekst Kornhausera stanowi cenny komentarz do krajobrazów wiedeńskiego malarza i ich niepowtarzalne, bo uzupełnione własnym odczuciem, dopowiedzenie.

Spacer po bezludnym zaułku, innymi słowy: ucieczka! Wokoło dachy, głosy, szmery. Rzucam patykami w okna, wchodzę do opuszczonych mieszkań, zostawiam to, co nie jest mi już potrzebne. Dziwne, bo gdzieniegdzie na sznurach suszy się pranie. Nie mogę odnaleźć przesmyku między obsypującymi się murami, trzymam w ręce latarkę. W pokojach zdarte plakaty, czarne dywany. Książki zdążyły przyrosnąć do regałów. W funeralnych wannach krzyże i karpie łuski. Z każdym krokiem jestem lżejszy, z każdym piętrem topnieją wyrąbane w kamieniu stopnie (Kornhauser 2013, 134-135).

Przed podróżnikiem, który stawia niepewne kroki w bezludnym mieście, otwierają się pejzaże zniszczeń. W obliczu powszechnego zamierania, również wędrowiec doświadcza utraty - uwiedziony sennym mrokiem, jak zaklęty zostawia to, co nie wydaje się mu potrzebne, maleje, znika... Sygnały realności stają się coraz mniej pewne. Są jak złe przeczucie.

Kiedy nad Europą pojawiło się widmo Wielkiej Wojny, Schiele przygotowywał się do małżeństwa z Edith. Jego twórczość w tym okresie i w kolejnych latach stopniowo ulegała wyciszeniu, malarz zwracał się $\mathrm{w}$ stronę przedstawień realistycznych (Kuryluk 1974, 277), rezygnował z tego, co we wcześniejszej twórczości oburzało i gorszyło opinię publiczną. Zdawało się, że jego rozpędzona wyobraźnia znajdowała wreszcie ukojenie, rytm życia zwalniał.

W 1915 roku, po dwukrotnym odroczeniu powołania, Schielego zmobilizowano. Nie walczył na froncie - zyskał przywilej, by większą część służby odbyć we własnej pracowni (Sabarsky 1996, 16). Choć mogłoby się wydawać, że podczas wojny - i fizycznie i duchowo, artystycznie - znajdował się daleko poza nurtem tragicznych wydarzeń, doskonale zdawał sobie 
sprawę z sytuacji, w jakiej znalazła się Europa. Świat, który znał, odchodził. W jednym z listów do siostry z tego okresu Schiele pisał:

Żyjemy w czasach największego przełomu, jaki kiedykolwiek widział świat. Przyzwyczailiśmy się do największych wyrzeczeń - giną setki tysięcy ludzi - i każdy, żywy czy konający, musi nieść swój los - staliśmy się twardzi i nie lękamy się niczego. To, co było przed rokiem 1914, należy do innego świata (Kuryluk 1999, 38).

Znów intuicja malarza okazała się niezwykła. Schiele zmarł podczas epidemii grypy hiszpanki, w dniu, w którym zwycięzcy I wojny światowej ogłosili upadek Cesarstwa Austro-Węgierskiego (Great Masters. Egon Schiele 1994, 31). Pustka, którą nieustannie przewidywał, stała się realna właśnie wtedy, kiedy jego życie osobiste i artystyczne ustabilizowało się - Edith była w ciąży, a on sam wyrósł na najbardziej cenionego z wiedeńskich malarzy. Śmiały i dumny bohater Autoportretu nie zdążył odwrócić tragicznego przeznaczenia - melancholijne przeczucie przywiodło go do „ciemnego kresu”.

\section{Bibliografia}

Bałus Wojciech, 1996, Mundus melancholicus, Kraków.

Bieńczyk Marek, 1998, Melancholia. O tych, co nigdy nie odnajdq straty, Warszawa.

Bik Katarzyna, 1996, Drapieżna kreska, „Gazeta Wyborcza”, nr 290.

Draguła Andrzej, 2013, Bluźnierstwo. Między grzechem a przestępstwem, Warszawa.

Fisher Georg Wolfgang, 1998, Egon Schiele 1890 - 1918. Pantomimen der Lust Visionen der Sterblichkeit, Köln.

Kandinsky Wassily, 1996, O duchowości w sztuce, Łódź.

Klibansky Raymond, Panofsky Erwin, Saxl Fritz, 2009, Saturn i melancholia. Studia z historii, filozofii, przyrody, medycyny, religii oraz sztuki, Kraków.

Kuryluk Ewa, 1974, Wiedeńska apokalipsa. Eseje o sztuce i literaturze wiedeńskiej około 1900, Kraków.

Kuryluk Ewa, 1999, Jesień świata, „Gazeta Wyborcza”, nr 223, dod.

Lionel Richard, Armin Arnold, 1996, Encyklopedia ekspresjonizmu, Warszawa.

Sabarsky Serge, 1996, Egon Schiele [katalog wystawy], Kraków.

Szarota Piotr, 2013, Wiedeń 1913, Gdańsk.

Sarzyński Piotr, 1997, Malowana niemoralność, „Polityka”, nr 1 (2070).

Szyller-Szkolnik Chaim, 1912, Najpewniejszy sposób poznania siebie i bliźnich:

krótki zarys chiromancji, fizjognomiki, frenologji, grafologji i astrologji,

Warszawa.

Śniedziewski Piotr, 2011, Melancholijne spojrzenie, Kraków.

The Great Masters. Egon Schiele, 1993, London.

Urbanowicz Andrzej, 1997, Egon Schiele, „Opcje”, nr 3.

Zeńczak Anna, 1997, Egon Schiele w Krakowie, „Plastyka i Wychowanie”, nr 3. 
Wybrane witryny i galerie internetowe poświęcone twórczości Egona Schielego:

https://www.artsy.net/artistlegon-schiele

http://www.egon-schiele-jahrbuch.at/index.html

http://www.egon-schiele.net/

http://www.gnosis.art.pl/iluminatornia/sztuka_o inspiracjilegon schiele

http://www.leopoldmuseum.org/en/leopoldcollection/focus/Schiele

http://www.zeno.org/Kunstwerke/A/Schiele, + Egon

\section{O Autorce}

Agata Szulc-Woźniak - doktorantka na Wydziale Filologii Polskiej i Klasycznej Uniwersytetu im. Adama Mickiewicza w Poznaniu. Pracuje nad monografią twórczości poetyckiej Joanny Pollakówny. Promotorką powstającej rozprawy jest prof. UAM dr hab. Katarzyna Kuczyńska-Koschany. 
